\title{
Contributing factors to potential turnover in a sample of South African management-level employees.
}

\author{
Rudolph Muteswa: University of KwaZulu-Natal \\ Karen Ortlepp: University of KwaZulu-Natal
}

\begin{abstract}
SYNOPSIS
Purpose: The overall purpose of this study was to explore the extent to which a number of key organisational variables influence the potential decision to leave the organisation in a sample of managerial-level employees. Organisational variables focused on included: career path strategies, management style, intrinsic and extrinsic rewards, team dynamics, training and development opportunities, and work/life balance.
\end{abstract}

Methodology: An exploratory and descriptive research design was adopted. A questionnaire was developed by the researchers based on the related literature. 106 MBA students based in KwaZulu-Natal participated in the study.

Findings: The three aspects of internal organisational functioning found to have a significant influence on the participant's potential turnover considerations were: management/leadership style, career path strategies and rewards.

Value of the research: According to the Department of Labour (2008:5) there is need for an additional 22600 managers in various professions in South Africa. As a result of the skills shortages, South African organisations find themselves competing with international organisations for managerial-level employees, resulting in a 'war for talent'. This research is of significant value to organisations as it provides information relevant to the design and support of talent management and retention strategies in South African organisations.

\section{KEY WORDS}

Talent management; retention strategies; voluntary turnover; managerial-level employees.

\section{INTRODUCTION}

As a result of the skills shortages, South African organisations are competing with international organisations for talented employees and this has led to the 'war for talent'. The term 'war for talent' for the purposes of this paper means competing for the employment of managerial-level employees by both South African and international organisations. The emigration of skilled employees to other countries has exacerbated the situation of skills shortages in the current South African labour market (Nel, Werner, Haasbroek, Poisat, Sono and Schultz, 2008:2). This study focused on managerial-level employees in particular and explored the internal organisational factors impacting on managerial-level employees' consideration to leave their organisations.

In the literature, 'managerial-level employee' is defined in the context of talent management. The word 'talent' has various meanings; that is, it can be used to refer to an individual's skill or ability and/or to an individual's intellectual capacity level, accomplishments and areas of interests (Joubert, 2007:6). The term 'managerial-level employee', for the purposes of this study, refers to individuals who have been accepted to study towards a Master of Business Administration (MBA) degree at the University of KwaZulu-Natal (UKZN) Graduate School of Business. 'Managerial-level employees', for the purposes of this study, also includes knowledge workers who are often employees who work in the information technology and science industries and are aiming to be in senior management positions (Beckstead and Gellatly, 2004:12). The term also includes various professions such as teachers, nurses, marketers, human resources specialists, accountants, doctors, engineers, lecturers, administrators, supervisors and many other professionals aiming to be in senior managerial posts in their organisations.

The overall purpose of this study was to explore the contributing factors to potential turnover as perceived by a sample of South African management-level employees. A thorough review of the literature pertaining to factors influencing the retention of key groups of employees (e.g. knowledge workers) in 
various organisational settings was initially undertaken so as to identify the areas of focus in this study. In particular, factors such as intrinsic and extrinsic rewards, leadership style, career path strategies, development opportunities, team dynamics and work/life balance were identified and formed the core focus areas of this study. Given that the research was to be based on managerial-level employees all pursuing studies towards an MBA, it was decided also to give some attention to the potential influence of achieving an MBA on participants' turnover intentions. The specific aims of this study were, therefore, to determine the level of influence each of the following factors has on the potential turnover intentions of a sample of managerial-level employees:

- Intrinsic and extrinsic rewards

- Leadership/management style

- Organisational career-path strategies

- Work/life balance challenges

- Organisation's training and development strategy

- Team dynamics

- Achieving an MBA

The above factors were explored within a sample of MBA students based in KwaZulu-Natal. "KwaZuluNatal is South Africa's third smallest province taking up 7,7 percent of South Africa's land area. It contributes R324 billion (at current prices) or 16,2 percent towards the country's Gross Domestic Product (GDP)" (Davis, 2010). While this study was based in KZN, it is of significant benefit to South African organisations in general as the findings will help provide them with empirical data that they may use in designing and supporting their talent management (attraction and retention) strategies.

\section{LITERATURE REVIEW}

A brief overview of the literature pertaining to the skills shortages in South Africa, the 'war for talent', contributing factors to staff turnover and organisational talent management strategies is provided in this section. This literature forms the contextual basis for the empirical study forming the focus of this paper.

\section{Skills Shortages and the 'war for talent' in South Africa}

"The term 'skills shortages' is an amorphous concept that encapsulates many specific components, but at the heart of the matter is the idea that the demand for certain skills exceeds supply." (Daniels, 2007:1). South Africa is facing a critical situation of skills shortages (Erasmus, Loedolff, Mda and Nel, 2006:50). One of the key contributing factors to this is South Africa's education system which is not producing enough learners with mathematical, information technology and science related subjects. This is leading to few learners enrolling at Universities of Technology and universities to further their studies in these fields. This situation is exacerbated by the number of skilled professionals who are emigrating to other countries (Nel et al., 2008:418). South Africa does not have adequate skilled professionals and the option of recruiting skills from other countries is made difficult by the legal requirements needed to obtain work permits in the country (Isaacson, 2007:27).

Two other factors contributing to the high skills shortages in South Africa include HIV/AIDS and developments in the telecommunications sector. The Human Immuno-deficiency Virus (HIV) is one of the factors contributing to skills shortages in South Africa. HIV/AIDS is eliminating both skilled and unskilled employees and this results in the reduced human capital realisation rates in South Africa (Erasmus et al., 2006:59). The growth and development of the technology and telecommunications industry rapidly increased over the past decade and this has led to an increase in the skills shortages as it has led to the expansion and diversification of new market opportunities such as software programming, design and many others (Nxele, 2008:4).

The skills shortages resulting from the above factors have led to the 'war for talent'. Because of the high demand for managerial-level employees globally, organisations that fail to out-compete their competitors in the 'war for talent' experience high employee turnover rates (Taylor, 2003:6). South African 
organisations are faced with the critical task of retaining their managerial-level employees in order to reduce their managerial-level employee turnover rates.

\section{Employee Turnover}

Employee turnover statistics are being used by organisations to examine the impact turnover has on their operations. Managerial-level employees, especially those with scarce skills, are consistently being offered well-paying jobs globally and some of these offers are too attractive for them to resist (Capelli, 2000:109). "Labour turnover is the analysis of the numbers of people leaving the organisation and provides the data for use in supply forecasting, so that calculations can be made on the number of people lost who may have to be replaced" (Armstrong, 2006:373). Therefore, when managerial-level employees decide to resign or even when they are dismissed they contribute to an organisation's turnover rate. The different types of turnover that may affect South African organisations are many, but the focus of this study is on voluntary turnover of managerial-level employees from their organisations. 'Involuntary turnover' occurs when an organisation dismisses or retrenches its employees because their services are no longer needed (Fisher, Schoenfeldt and Shaw 2003:766). This could be caused by factors beyond the organisation's control, that is, macro-environmental factors such as the economy, legislation and technology. 'Voluntary turnover' rate ignores involuntary departures such as resignations, dismissals and redundancies (Brown, 2008).

The literature clearly points-out that there are more than 30 causes for voluntary employee turnover in organisations (Blake, 2006). However, 10 most common reasons for leaving an organisation have been identified in the literature (Blake, 2006). These are discussed briefly. The first common reason why employees leave is the existence of a poor relationship between the employee and his/her immediate manager. There is a saying that "people leave managers, not organisations" (Blake, 2006). Many employees decide to resign from an organisation as a result of conflict they may be having with their immediate managers (Armstrong, 2006:380). The lack of a career advancement plan is another reason why employees leave their organisations. This results in high job dissatisfaction leading the manageriallevel employees to look for alternative employment thereby increasing the employee turnover rates of an organisation (Grobler, Warnich, Carrell, Elbert and Hatfield, 2006:126).

Another reason why employees leave their organisation is due to the poor match between the employee and the job or the organisation. A person-organisation fit is when a person and an organisation have common characteristics and/or meet each other's needs. Therefore, if the organisation is not meeting the employees' needs, their intentions to leave are increased which results in them making the decision to quit (Sekuguchi, 2004:182). Employees leave their organisations when the compensation they are receiving from their employers is not competitive (Harman, Lee, Mitchell, Felps and Owens, 2007:51). In the South African context research has established that the level of pay dispersion and pay inequality within organisations drives turnover (Luyt, 2008:1). Employees also leave when rewards, such as bonuses and incentives, are not linked to performance (Blake, 2006). The need to have stimulating and meaningful work also influences employees to leave their organisations (Harman et al., 2007:51). In all organisations some jobs are monotonous, lack career progression and are generally not interesting; thus the employees' intentions to leave are increased.

Employees have been found to leave their organisations due to the lack of appreciation, recognition and rewards. Recognition is a critical ingredient in sustaining employee performance ( $\mathrm{Nel}$ et al., 2004:64). It has also been established that managers can motivate and inspire their employees to go the extra-mile at the workplace through recognising and appreciating their good work performance (Frauenheim, 2010:1). Another reason why employees leave their organisations is because of insufficient coaching and feedback. Coaching is done when highly skilled managers direct the activities of low-level and inexperienced managerial-level employees in order to assist them in building up their work performance and expanding their knowledge by helping them deal with difficult work situations thus enabling their career growth (DuBrin, 2008:359). 
Aspects related to the dynamics of the team in which quality of people an employee works can influence a person's decision to leave their organisation. This is referred to as contagion turnover and it generally occurs when an employee considers leaving an organisation after noticing his or her co-workers searching for alternative employment elsewhere (Felps, Mitchell, Hekman, Lee, Holtman and Harman, 2009). A workplace is not conducive to good performance if an employee has co-workers who are complainers and who perceive everything as wrong, employees who only do enough work to secure their jobs with no extra effort, and employees who consistently disagree with management, resist change initiatives and do not support their co-workers (Armstrong, 2006:380).

Lastly, insufficient alignment of how the employee's work achieves organisational objectives and how the employee can be a greater success is one of the common reasons why employees leave their organisations. In organisations, employees are only familiar with how to do their own jobs, and often are unaware of the importance of their jobs to both internal and external customers and the level of positive contribution their jobs have to organisations and how it enables the organisation to achieve its goals and objectives. This helps employees to be motivated and maintain their current work performance (Blake, 2006).

This literature points out that there are various reasons why employees, in general, leave their organisations. The current study focuses specifically on the perceptions of managerial-level employees. Much of the literature on employee turnover described earlier emanates from authors based in countries other than South Africa. The purpose of this study is to explore these issues within the South African context and to focus explicitly on the views of managerial-level employees who are based in the KZN province.

\section{Talent Management Strategies}

Given the above-mentioned reasons of employee turnover organisations have started to develop and adopt various talent management strategies. The term 'talent management strategy' is an umbrella term which typically includes talent retention strategies (Armstrong, 2006:397). Talent needs to be harnessed strategically for organisations to have effective talent management (Meyer and Litheko, 2007:8). There are various interrelated elements of talent management that have been adopted by organisations. In a highly competitive labour market, employers identify various attraction strategies, including employer branding and targeted recruitment and selection (Armstrong, 2006:396). Employer branding is the reputation an organisation has in the labour market and its ability to create employee attachment to the organisation as an ideal place to work (Davies, 2008:668). Organisations have discovered that intellectual capital, that is, the minds and hearts of employees, is critical to their success; hence, they are now putting more effort into attracting, nurturing and retaining their managerial-level employees through employer branding and by being 'employers of choice' (Armstrong, 2006:396). Work/life balance is a subcomponent of creating a great place to work. The conflict between work and life is experienced by most managerial-level employees working in South African organisations (Mostert and Koekmoer, 2007:1). It has been established in empirical studies that work-life conflict results in managerial-level employees having high absenteeism rates and reduced quality work results (Fisher et al., 2003:644). Leadership/management style being used by an organisation is another way of retaining managerial-level employees as managerial leadership and supervision have an important impact on motivation, employee loyalty, flexibility and satisfaction of employees (Du Brin, 2008:350).

One of the most critical elements of talent management is offering highly competitive remuneration packages to employees as this highly motivates them (Bethke, 2007:28). According to a South African study conducted by Kinnear and Sutherland (2000) in which 104 knowledge workers from financial services, science and technology sectors participated, competitive remuneration packages and performance incentives were the most important factor contributing to organisational commitment (Kinnear and Sutherland, 2000:24). Another element of talent management strategies is career development. Organisations should involve managerial-level employees in formulating career development plans so that they have a clear vision of where their career path is heading, especially if the managerial-level employee is career committed (Cook, 2006:32). Training and development is one of the 
human resources management aspects that enables organisations to facilitate their career development plans (Gilley and Maycunich, 2000:260). The main purpose of training is to enable the organisation to accomplish its aim of increasing the value of its human resources, address their personal growth needs and reduce employee obsolescence (Grobler et al., 2006:303). Organisations that invest in training and development of their managerial-level employees not only save money, but can also nurture and develop their own talent (Ryan, 2009:2).

The above points provide a brief indication of the focus areas in talent management. The current study contributes to the existing literature base in that it focuses explicitly on managerial-level employees within the South African context. The findings have the potential to confirm those of previous studies in this field and to assist organisations in their strategies to attract and retain a much needed resource, namely, managerial-level employees. The data collection method and sample size that was used in this study will be presented in the following section.

\section{RESEARCH METHODOLOGY}

The research methodology adopted in this study, including design, sample description, measuring instrument and statistical analyses, is outlined in this section.

\section{Research design}

The research design adopted in the study was exploratory, cross-sectional and descriptive.

\section{Sample}

A purposive sampling technique was used in the study as the target population was chosen to serve a particular purpose (Zikmund, 2003:382). The targeted population in the current study comprised of managerial-level employees currently working in KZN-based organisations and who met the entry requirements of UKZN's MBA. All registered MBA students at the Graduate School of Business (GSB) of UKZN formed the target population. At the time of conducting the study, the number of students registered at the GSB was 140. As such, 140 questionnaires were distributed to the target sample and 115 completed questionnaires were returned. Nine questionnaires had to be excluded as they were not completed fully. Hence, the final sample comprised of 106 respondents equating to a $76 \%$ response rate.

The sample of respondents consisted of $67.9 \%(n=72)$ males and $32.1 \%(n=34)$ females. The average age of the respondents was 34.16 years and the age ranged from between 25 and 55 years. In the study $64.8 \%(n=68)$ of the respondents were married, $34.3 \%(n=36)$ were single and $1 \%(n=1)$ was divorced. The three most commonly spoken home languages were: English with $57.5 \%(n=61)$, Zulu with $29.2 \%$ $(n=31)$ and lastly Xhosa with $2.8 \%(n=3)$. The average number of dependants of this sample of managerial-level employees was 2.23. In terms of education, $44.8 \%(n=47)$ of respondents had a Bachelor's degree, while $24.8 \%(n=26)$ had an Honours degree. The average tenure in respondents' current organisation of employment was 6.63 years. In the study the majority of the respondents were employed in the Manufacturing (22.6\%; $n=24)$, Public Service $(16 \% ; n=17)$ and Education $(11.3 \% ; n=12)$ sectors.

\section{Measuring Instrument}

A self-designed questionnaire was used for data collection. Relevant literature formed the basis for the development of the research instrument. The measuring instrument was named, Contributing Factors to Staff Turnover (CFST) and the components related to the internal organisational factors contributing to potential staff turnover formed the focus of this study. The relevant measures were:

- $\quad$ CFST Career-paths (comprised of 6 items)

- $\quad$ CFST Management Style (comprised of 9 items)

- CFST Rewards(comprised of 10 items)

- CFST Team Dynamics (comprised of 4 items)

- CFST Training and Development (comprised of 8 items) 
- $\quad$ CFST MBA (comprised of 1 item)

- CFST Work/life (comprised of 8 items)

The aim of this study was not to undertake an in-depth investigation into the nature and role of an MBA in managerial-level employees' career paths and, as such, only one item was included to determine whether or not having an MBA will influence participants' intentions to leave their organisations. Both open-ended and closed questions were included in the questionnaire. The level of influence an item had on the respondents' consideration to leave their current organisations was measured by utilising the following 4point Likert scale: 'No Influence', 'Little Influence', 'Significant Influence' and 'Highly Significant Influence'. Reliability is important when using a measuring instrument as it helps show whether the instrument is free of errors or not. One way of ensuring internal reliability is calculating Cronbachs alpha coefficients (Blumberg, Cooper and Schindler, 2005:455). The CFST instrument was found to have a Cronbach Alpha of 0.95 .This is an indication of high internal reliability (Lowenthal, 2001:12) which is most pleasing in a newly devised questionnaire. The Cronbach Alpha coefficients for the 7 components are presented in Table 1 below:

Table 1: Cronbach Alpha Results

\begin{tabular}{|l|l|}
\hline Measuring Instrument & Cronbach Alpha \\
\hline CFST Total & 0.952 \\
\hline CFST Rewards & 0.778 \\
\hline CFST Management Style & 0.871 \\
\hline CFST Career paths & 0.739 \\
\hline CFST Training and Development & 0.855 \\
\hline CFST Work/life & 0.798 \\
\hline CFST Team Dynamics & 0.684 \\
\hline CFST MBA & $\begin{array}{l}\text { Not computed as it is made up of one item } \\
\text { only }\end{array}$ \\
\hline
\end{tabular}

\section{Statistical Analysis}

The statistical programme used to determine the levels of internal reliability and subsequent statistical analyses of the data set was the SPSS statistical package. The data were analysed using descriptive statistics, namely: means, medians, standard deviation, minimum and maximums for the instrument. Frequencies of responses on all the open-ended questions were calculated.

\section{FINDINGS}

The findings are presented firstly by exploring the descriptive statistics and then discussing the findings relating to each research question and objective. The descriptive statistics related to the CFST are depicted in Table 2 below: 
Table 2: Descriptive Statistics

\begin{tabular}{|c|c|c|c|c|c|c|}
\hline & Mean & Median & $\begin{array}{c}\text { Std. } \\
\text { Deviation }\end{array}$ & Minimum & Maximum & Number of items \\
\hline Total CFST & 154.56 & 153.5000 & 25.94645 & 65.00 & 222.00 & 56 \\
\hline CFST Rewards & 29.09 & 30.0000 & 5.27730 & 11.00 & 40.00 & 10 \\
\hline $\begin{array}{c}\text { CFST } \\
\text { Management } \\
\text { style }\end{array}$ & 26.50 & 26.0000 & 5.64885 & 10.00 & 36.00 & 9 \\
\hline $\begin{array}{c}\text { CFST Career- } \\
\text { paths }\end{array}$ & 17.81 & 18.0000 & 3.36682 & 6.00 & 24.00 & 6 \\
\hline $\begin{array}{c}\text { CFST } \\
\text { Training \& } \\
\text { Development }\end{array}$ & 22.05 & 22.0000 & 5.04151 & 9.00 & 32.00 & 8 \\
\hline \begin{tabular}{c} 
CFST Work/life \\
\hline $\begin{array}{c}\text { CFST Team } \\
\text { Dynamics }\end{array}$
\end{tabular} & 20.58 & 21.0000 & 4.93182 & 9.00 & 31.00 & 8 \\
\hline \begin{tabular}{c} 
CFST MBA \\
\hline
\end{tabular} & 2.72 & 3.0000 & .98542 & 1.00 & 4.00 & 1 \\
\hline
\end{tabular}

The results in Table 2 show that the Total CFST Rewards mean score was 29.09, given the minimum and maximum scores of 11.00 and 40.00 respectively, which indicates that both intrinsic and extrinsic rewards are identified by the managerial-level employees as factors that would influence their decision to leave or remain in their organisations. Therefore, if the managerial-level employees do not receive competitive remuneration packages this would have a relatively strong influence on their intention to consider leaving their employers, as indicated by the literature. The results in Table 2 depicted that the CFST Management Style Total mean score was 26.50, given the minimum and maximum scores of 10.00 and 36.00 respectively. Effective leadership/management style helps create mutual understanding amongst the managerial-level employees and this motivates high work performance, at the same time reducing their intentions to leave (French, 2003:81).

This study found that the career-path strategies currently being used by KZN-based organisations influence the majority of the managerial-level employees' intention to leave. This is depicted in Table 2 above with the mean score of 17.81 which was high, with the minimum score being 6.00 and maximum score 24.00 for the career-path strategies component of the CFST. Career development is a continuous process and enables employees to develop and grow their work-related interests (career) (Schreuder and Coetzee, 2006:260). The results in Table 2 depict that the mean score of Training and Development Strategy was 17.81 with the minimum score being 6.00 and the maximum score 24.00 which indicates that the respondents are strongly influenced in their intentions to leave their organisations by the type of training and development strategy being used. Training and development is one of the human resources aspects that enables organisations to facilitate their career development plans (Grobler et al., 2006:303).

The results in Table 2 show that the Total Work/life mean score was 20.58, given the minimum and maximum scores of 9.00 and 31.00 respectively. This indicates that conflict between work and life is experienced by most of the managerial-level employees working in South African organisations (Mostert and Koekmoer, 2007). The CFST Team Dynamics Total mean score was 13.91, given the minimum and maximum scores were 6.00 and 20.00 respectively. This shows that a majority of KZN managerial-level employees' intentions to leave their organisations are influenced by the nature of the team dynamics in the organisation. As depicted in Table 2 regarding the completion of an MBA degree, the mean score was 2.72 which was high, with the minimum score being 1.00 , whilst the maximum score was 4.00 . The results show that when the managerial-level employees complete their MBA degree they are more likely 
to leave their current employers. It may be argued that this may be due to the fact that after completing their MBA degrees, the respondents will become more marketable in the South African and international job market and this results in the managerial-level employees having high intentions to leave to work in other organisations that may offer them better opportunities.

The findings relating to the specific focus areas in the research aims will be discussed in the following section. The ratings of the four-point Likert scale are presented as per specific Focus area of the CFST in a table format. Findings related to the level of influence intrinsic and extrinsic rewards have on the managerial-level employees' consideration to leave their organisations are presented in Table 3 below:

Table 3: Perceived influence of intrinsic and extrinsic rewards on respondents' consideration to leave their organisations

\begin{tabular}{|l|l|l|l|l|}
\hline Item & $\begin{array}{l}\text { No } \\
\text { Influence } \\
(\%)\end{array}$ & $\begin{array}{l}\text { Little } \\
\text { Influence } \\
(\%)\end{array}$ & $\begin{array}{l}\text { Significant } \\
\text { Influence } \\
(\%)\end{array}$ & $\begin{array}{l}\text { Highly Significant } \\
\text { Influence } \\
(\%)\end{array}$ \\
\hline Dissatisfaction with remuneration & 4.7 & 23.6 & 35.8 & 35.8 \\
\hline Pay based on commission only & 40.0 & 24.8 & 19.0 & 16.2 \\
\hline Pay not linked to performance & 3.8 & 18.9 & 29.2 & 48.1 \\
\hline $\begin{array}{l}\text { Lack of work achievement } \\
\text { recognition }\end{array}$ & 2.9 & 18.1 & 46.7 & 32.4 \\
\hline Poor working conditions & 13.2 & 16.0 & 40.6 & 30.2 \\
\hline $\begin{array}{l}\text { Lack of recognition for your } \\
\text { qualifications through the pay } \\
\text { system }\end{array}$ & 1.9 & 11.3 & 47.2 & 39.6 \\
\hline $\begin{array}{l}\text { Lack of recognition for your } \\
\text { experience through the pay system }\end{array}$ & 3.8 & 17.3 & 50 & 28.8 \\
\hline Lack of freedom to act on the job & 8.7 & 23.1 & 40.4 & 27.9 \\
\hline Lack of challenging work & 9.5 & 19.0 & 36.2 & 35.2 \\
\hline Dissatisfaction with fringe benefit & 6.7 & 27.9 & 36.5 & 28.8 \\
\hline
\end{tabular}

In order to determine the most influential items, responses from the 'Significant Influence' and 'Highly Significant Influence' categories were collated for all the sets of data. Thus, for each focus area of the CFST, the 3 most influential items will be identified explicitly. The 3 most influential items on the managerial-level professionals' decisions to leave their current organisations as related to this focus area included: 'the lack of recognition for your qualifications through the pay system' (86.8\%); 'the lack of workachievement recognition' (79.1\%); and 'the lack of recognition of experience through the pay system' (78.8\%).

The study findings related to the role played by leadership/management style in respondents' consideration to leave their organisations are presented in Table 4 below. 
Table 4: Perceived influence of leadership/management style on respondents' consideration to leave

\begin{tabular}{|l|l|l|l|l|}
\hline Item & $\begin{array}{l}\text { No } \\
\text { Influence } \\
(\%)\end{array}$ & $\begin{array}{l}\text { Little } \\
\text { Influence } \\
(\%)\end{array}$ & $\begin{array}{l}\text { Significant } \\
\text { Influence } \\
(\%)\end{array}$ & $\begin{array}{l}\text { Highly Significant } \\
\text { Influence } \\
(\%)\end{array}$ \\
\hline $\begin{array}{l}\text { Authoritative leadership style of your } \\
\text { manager }\end{array}$ & 4.7 & 26.4 & 31.1 & 37.7 \\
\hline Exclusion from decision making & 5.8 & 19.2 & 37.5 & 37.5 \\
\hline $\begin{array}{l}\text { Lack of progressive leadership which } \\
\text { allows you to do things differently }\end{array}$ & 1.9 & 17.1 & 40.0 & 41.0 \\
\hline $\begin{array}{l}\text { Lack of involvement in management } \\
\text { and business decisions }\end{array}$ & 3.8 & 16.0 & 39.6 & 40.6 \\
\hline $\begin{array}{l}\text { Lack of clear expectations and } \\
\text { direction from your immediate } \\
\text { manager }\end{array}$ & 6.7 & 20.0 & 42.9 & 30.5 \\
\hline An unapproachable manager & 5.7 & 31.4 & 31.4 & 31.4 \\
\hline An unfriendly manager & 9.5 & 39.0 & 30.5 & 21.0 \\
\hline $\begin{array}{l}\text { Management's lack of consideration of } \\
\text { employees' concerns }\end{array}$ & 8.6 & 17.1 & 42.9 & 31.4 \\
\hline $\begin{array}{l}\text { Management's lack of implementation } \\
\text { of employees' suggestions }\end{array}$ & 8.5 & 29.2 & 37.7 & 24.5 \\
\hline
\end{tabular}

The three most influential items responses in this focus area were identified. These included the following: 'the lack of progressive leadership which allows you to do things differently' (81\%); 'the lack of involvement in management and business decisions' (80.2\%); and the third item was 'exclusion from decision-making' with $75 \%$. Study findings on the level of influence current career-path strategies being used by KZN organisations have on managerial-level employees' to leave their organisations, are presented in Table 5 below.

Table 5: Perceived influence of career-path strategies being used by South African organisations on the respondents' consideration to leave

\begin{tabular}{|l|l|l|l|l|}
\hline Item & $\begin{array}{l}\text { No } \\
\text { Influence } \\
(\%)\end{array}$ & $\begin{array}{l}\text { Little } \\
\text { Influence } \\
(\%)\end{array}$ & $\begin{array}{l}\text { Significant } \\
\text { Influence } \\
(\%)\end{array}$ & $\begin{array}{l}\text { Highly Significant } \\
\text { Influence } \\
(\%)\end{array}$ \\
\hline Lack of a clear career-path & 4.8 & 12.4 & 36.2 & 46.7 \\
\hline External employee hiring policies & 14.2 & 43.4 & 22.6 & 19.8 \\
\hline $\begin{array}{l}\text { Poor use of performance criteria for } \\
\text { promotion decisions }\end{array}$ & 1.9 & 14.2 & 45.3 & 38.7 \\
\hline $\begin{array}{l}\text { Lack of effective succession } \\
\text { planning }\end{array}$ & 3.8 & 16.0 & 46.2 & 34.0 \\
\hline $\begin{array}{l}\text { Lack of employee career counselling } \\
\text { and workshops }\end{array}$ & 11.3 & 34.0 & 34.0 & 20.8 \\
\hline $\begin{array}{l}\text { Failure to achieve personal career } \\
\text { goals }\end{array}$ & 3.8 & 13.2 & 46.2 & 36.8 \\
\hline
\end{tabular}

The 3 most influential items related to this focus area included the following: 'the poor use of performance criteria for promotion decisions' with $84 \%$; 'failure to achieve personal career goals' with $83 \%$; and 'the lack of a clear career path' with (82.9\%). The research findings related to the influence of work/life balance issues on managerial-level employees are presented in Table 6. 
Table 6: Perceived influence of work/life balance issues on the respondents' consideration to leave

\begin{tabular}{|l|l|l|l|l|}
\hline Item & $\begin{array}{l}\text { No } \\
\text { Influence } \\
(\%)\end{array}$ & $\begin{array}{l}\text { Little } \\
\text { Influence } \\
(\%)\end{array}$ & $\begin{array}{l}\text { Significant } \\
\text { Influence } \\
(\%)\end{array}$ & $\begin{array}{l}\text { Highly Significant } \\
\text { Influence } \\
(\%)\end{array}$ \\
\hline Work and personal life conflict & 11.7 & 31.1 & 33.0 & 24.3 \\
\hline $\begin{array}{l}\text { Lack of family/social life due to high } \\
\text { work demand }\end{array}$ & 11.4 & 26.7 & 31.4 & 30.5 \\
\hline $\begin{array}{l}\text { Lack of work/life balance assistance } \\
\text { programmes in this organisation }\end{array}$ & 9.4 & 33.0 & 35.8 & 21.7 \\
\hline $\begin{array}{l}\text { Lack of time for personal life outside } \\
\text { of work }\end{array}$ & 12.3 & 31.1 & 30.2 & 26.4 \\
\hline Inability to work from home & 19.8 & 48.1 & 13.2 & 18.9 \\
\hline $\begin{array}{l}\text { Lack of recreational facilities at } \\
\text { work }\end{array}$ & 21.0 & 43.8 & 23.8 & 11.4 \\
\hline $\begin{array}{l}\text { Lack of support from the } \\
\text { organisation to deal with work/life } \\
\text { balance challenges }\end{array}$ & 5.7 & 40.6 & 34.0 & 19.8 \\
\hline Inflexible work time schedule & 15.1 & 34.0 & 33.0 & 17.9 \\
\hline
\end{tabular}

With reference to this focus area, the following 3 items were found to have the most significant influence. 'Lack of family /social life due to high work demand' (61.9\%);'lack of work/life balance assistance programmes in this organisation' (57.5\%); and 'work and personal life conflict' $(57.3 \%)$. The study findings related to the level of influence an organisation's training and development strategy has on the managerial-level professionals' consideration to leave their organisations are presented in Table 7.

Table 7: Perceived influence of training and development strategy on the respondents' consideration to leave

\begin{tabular}{|l|l|l|l|l|}
\hline Item & $\begin{array}{l}\text { No } \\
\text { Influence } \\
(\%)\end{array}$ & $\begin{array}{l}\text { Little } \\
\text { Influence } \\
(\%)\end{array}$ & $\begin{array}{l}\text { Significant } \\
\text { Influence } \\
(\%)\end{array}$ & $\begin{array}{l}\text { Highly Significant } \\
\text { Influence } \\
(\%)\end{array}$ \\
\hline $\begin{array}{l}\text { Lack of training and development } \\
\text { opportunities }\end{array}$ & 10.5 & 18.1 & 36.2 & 35.2 \\
\hline $\begin{array}{l}\text { Lack of training on new technological } \\
\text { systems }\end{array}$ & 11.3 & 32.1 & 36.8 & 19.8 \\
\hline $\begin{array}{l}\text { Lack of opportunities for } \\
\text { development in your area of } \\
\text { expertise }\end{array}$ & 3.8 & 11.3 & 41.5 & 43.4 \\
\hline $\begin{array}{l}\text { Lack of exposure to experts in your } \\
\text { profession }\end{array}$ & 6.7 & 24.8 & 41.9 & 26.7 \\
\hline $\begin{array}{l}\text { Lack of fairness on how candidates } \\
\text { are selected for training }\end{array}$ & 7.5 & 27.4 & 42.5 & 22.6 \\
\hline $\begin{array}{l}\text { Poor timing of training and } \\
\text { development programmes }\end{array}$ & 8.5 & 39.6 & 35.8 & 16.0 \\
\hline $\begin{array}{l}\text { Ineffective on-the-job training } \\
\text { methods }\end{array}$ & 13.3 & 31.4 & 39.0 & 16.2 \\
\hline $\begin{array}{l}\text { Ineffective off-the-job training } \\
\text { methods }\end{array}$ & 15.2 & 38.1 & 35.2 & 11.4 \\
\hline
\end{tabular}

In the study findings it is depicted that the 3 top most influential items related to an organisation's training and development strategy were the following: 'the lack of opportunities for development in their area of expertise' with $84.9 \%$; 'the lack of training and development opportunities' with $71.4 \%$; and thirdly 'the 
lack of exposure to experts in their professions' with $68.6 \%$. The level of influence Team Dynamics has on managerial-level employees' consideration to leave their organisations are presented in Table 8.

Table 8: Perceived influence of Team Dynamics on the respondents' consideration to leave

\begin{tabular}{|l|l|l|l|l|}
\hline Item & $\begin{array}{l}\text { No } \\
\text { Influence } \\
(\%)\end{array}$ & $\begin{array}{l}\text { Little } \\
\text { Influence } \\
(\%)\end{array}$ & $\begin{array}{l}\text { Significant } \\
\text { Influence } \\
(\%)\end{array}$ & $\begin{array}{l}\text { Highly Significant } \\
\text { Influence } \\
(\%)\end{array}$ \\
\hline Lack of respect and fair treatment & 4.7 & 16.0 & 31.1 & 48.1 \\
\hline $\begin{array}{l}\text { Co-workers who have a bad attitude } \\
\text { about working in this organisation }\end{array}$ & 11.3 & 44.3 & 29.2 & 15.1 \\
\hline $\begin{array}{l}\text { Co-workers who do not support each } \\
\text { other }\end{array}$ & 11.3 & 41.5 & 36.8 & 10.4 \\
\hline Lack of team work and support & 5.8 & 36.9 & 39.8 & 17.5 \\
\hline
\end{tabular}

The items that have the most significant or highly significant influence were 'lack of fair treatment' $(79.2 \%)$ and 'lack of team and support' (57.3\%). The study findings related to the level of influence of having an MBA on managerial-level employees are presented in Table 9.

Table 9: Perceived influence of Completion of MBA on respondents' consideration to leave

\begin{tabular}{|l|l|l|l|l|}
\hline Item & $\begin{array}{l}\text { No } \\
\text { Influence } \\
(\%)\end{array}$ & $\begin{array}{l}\text { Little } \\
\text { Influence } \\
(\%)\end{array}$ & $\begin{array}{l}\text { Significant } \\
\text { Influence } \\
(\%)\end{array}$ & $\begin{array}{l}\text { Highly Significant } \\
\text { Influence } \\
(\%)\end{array}$ \\
\hline Completion of your MBA degree & 10.5 & 34.3 & 27.6 & 27.6 \\
\hline
\end{tabular}

In the study it was found that the managerial-level employees are significantly influenced in their decision to leave by the completion of their post-graduate qualification (MBA) in their consideration to leave their current KZN-based organisations as the item had a total score of $(55.2 \%)$.

In order to explore the strength of each of the components of the CFST in relative terms, the means pertaining to each component were ranked. The 7 sub-components of the CFST have therefore been ranked in descending order and this order shows the relative level of influence they have on this group of managerial-level employees' consideration to leave their organisations. The means were calculated by dividing the total mean with the number of items in the sub-component. For instance, Work/life was 20.58 and the sub-component had 8 items $(20.58 / 8=2.57)$. These findings are presented in Table 10 below:

Table 10 : Ranking of the 7 sub-components of the CFST

\begin{tabular}{|l|c|}
\hline \multicolumn{1}{|c|}{ Sub-component rankings } & Mean \\
\hline CFST Career-paths & 2.97 \\
\hline CFST Management Style & 2.94 \\
\hline CFST Rewards & 2.90 \\
\hline CFST Team Dynamics & 2.78 \\
\hline CFST Training \& Development & 2.76 \\
\hline CFST MBA & 2.72 \\
\hline CFST Work/life & 2.57 \\
\hline
\end{tabular}


From the above table, it can be clearly seen that the three CFST sub-components that have the most influence on the managerial-level employees' decision to leave were aspects of the CFST related to Career-path, Management Style and Rewards.

Lastly, in order to explore further the different factors that would influence this sample of managerial-level employees' consideration to leave their South African organisations, the respondents were asked the following open-ended question: "What 5 things would influence your decision to leave your current organisation?" The findings are presented in Table 11. The frequencies in this table indicate the number of respondents who listed a particular issue as one of their five factors.

Table 11 : Five factors influencing respondents' decision to leave

\begin{tabular}{|lc|}
\hline FACTOR: & FREQUENCY \\
\hline Poor remuneration & 72 \\
Lack of career progression & 33 \\
Poor management & 26 \\
Better job and position offer & 24 \\
Poor working conditions & 20 \\
Job dissatisfaction & 20 \\
Lack of work recognition & 18 \\
Starting my own business & 17 \\
Lack of better fringe benefits & 13 \\
Lack of job challenge & 11 \\
Organisational politics & 9 \\
Need to change and explore other fields or sectors & 9 \\
Increased workload at work & 9 \\
Constant monitoring of work and procedures & 8 \\
Lack of training and development & 7 \\
Distance of travel to work & 6 \\
Family attention & 6 \\
Lack of equity/fairness at the workplace & 6 \\
Lack of job security & 5 \\
Lack of support by senior management & 5 \\
Racism & 4 \\
Bureaucracy & 4 \\
Winning the lottery & 3 \\
Opportunity to work overseas & 3 \\
Organisational restructuring & 2 \\
Industry downturn & 2 \\
Lack of job enrichment & 1 \\
Relocation to another province & 1 \\
Lack of motivation & 1 \\
Lack of diversity & 1 \\
Retirement & 1 \\
Achievement of MBA degree & 1 \\
\hline
\end{tabular}

According to Table 11 above, 'poor remuneration' and the 'lack of career progression' had the highest frequencies of 72 and 33 respectively, with 'poor remuneration' clearly the strongest trend to emerge as factors that would influence the managerial-level employees to leave their organisations. 


\section{DISCUSSION AND RECOMMENDATIONS}

The study findings, both from the CFST and the open-ended questions show that competitive remuneration packages are a significant influencing factor on managerial-level employees' considerations regarding leaving their current organisations. It was recommended that South African organisations should ensure that they make use of a compensation system that has both internal and external equity for its managerial-level employees. 'Internal' equity will help ensure that managerial-level employees are treated equally and paid according to their job grades and experience (Hunter, 2008:133). 'External' equity enables organisations to determine what its rivals are paying their managerial-level employees and also the current rates at both national and regional level so that they can be able to gauge their remuneration packages to make them more competitive (Shore, Tashchian and Jourdan, 2006:2579). According to a South African study that was conducted by Kinnear and Sutherland (2000:109) it was determined that competitive remuneration package was ranked number 1 out of 10 as the most preferred retention strategy by knowledge workers. This shows that the South African managerial-level employees need to earn competitive intrinsic and extrinsic rewards in order for them to be able to have reduced intentions to leave and be able to continue working for their current organisations for a longer time period.

In this study it was discovered that the current career-path strategies being used by South African organisations have a strong influence on respondents' decisions to leave their organisations. The study findings indicate that CFST Career-path Strategies was ranked number one on the total sample mean score rankings. Organisations should ensure that their current career-path strategies are able to help their managerial-level employees identify the different potential career-paths they can take to grow within the organisation and to identify their training and development needs to improve their skills and to achieve their personal career goals. Interestingly, the above study findings relate to those found in a study conducted by Sandweiss and Lewin, where 11 part-time MBA students were interviewed in-depth about employee retention. One of the factors that would make these managerial-level employees stay in their organisation was the opportunity for advancement (Sandweiss and Lewin, 2000:39). As they were about to complete their MBA degrees, these managerial-level employees were interested in using the knowledge they had acquired whilst studying towards their MBA degree. "A banker who was moving into management consulting commented that "I just knew that since I had an MBA, that I would be ready to move on to bigger and better things" (Sandweiss and Lewin, 2000:38). Thus, South African organisations that offer managerial-level employees opportunities to develop their skills, career and other growth opportunities will succeed in retaining them.

In the study findings CFST Management/leadership style was ranked number two on the total sample mean score rankings. From this study's findings it seems that South African organisations' top management should practise progressive leadership that allows managerial-level employees to have the freedom to act independently on the job as the study findings indicate that this greatly influences their decision to leave. It is also recommended that South African organisations' top management should use a democratic leadership style, that is, they should encourage high employee participation. This also helps to reduce tensions and conflicts at the workplace (Pop and Pop, 2008: 2605).

The study findings show that CFST Rewards was ranked number three on the total sample mean score rankings. Managerial-level employees who have significant working experience should be paid for their expertise as they will be adding value to the organisations as they require less training and development than new, inexperienced employees. The study findings relate to those found by Kinnear and Sutherland's research study in which 104 knowledge workers from financial services, IT and Science and Technology sectors participated to help determine what makes them committed to an organisation. Kinnear and Sutherland's study findings show that South African knowledge workers need to earn a competitive package but on top of that have the opportunity to earn performance based bonuses (Kinnear and Sutherland, 2000:24). Managerial-level employees' consideration to leave is increased if their work performance is not recognised and this is supported by the current study's results. The recognition of managerial-level employees should be 'contingent on' their performance, especially when an employee 
accomplishes an extraordinary task that makes an enormous contribution to the organisation (Nelson and Spitzer, 2003:23).

In the current study it was discovered that Team Dynamics has a strong influence on the managerial-level employees' consideration to leave their current organisations. "An employee derives interpersonal job satisfaction through interaction with peers, supervisors, subordinates and clients in the execution of the job" (Nel et al., 2004:19). Therefore, the development of social relationships will enable South African organisations to reduce the negative impact of employees with a bad attitude on other managerial-level employees and at the same time employees will more likely support each other in accomplishing their tasks (Felps et al., 2009). Lack of respect also affects the level of job satisfaction of a managerial-level employee. This is because if you treat another human being with respect they will feel valued and hence their morale at work is enhanced which results in high job satisfaction (Vansickle, 1999).

The lack of effective training and development opportunities also emerged in the current study as having a significant influence on managerial-level employees' intention to leave their organisations. Manageriallevel employees should be trained and developed in their area of expertise so that they can improve their skills and add value to the organisation. One strategy that can be considered in this regard is leadership coaching. This is a relatively new area in management development that can be used by South African organisations to improve the morale of employees with potentially positive consequences for overall organisational effectiveness (Day, 2000:518).

The study showed that work/life issues have some influence on the managerial-level employees' decision to leave, although they do not have as strong an influence as factors discussed earlier. If work/life balance is a challenge for managerial-level employees, organisations could consider implementing flexible work arrangements such as alternative workplace arrangements to help their managerial-level employees achieve work/life balance. Alternative workplace arrangements are currently being made possible by the advancements in technology such as home Internet connections, video-conferencing facilities and lap-tops as employees will be able to conduct their day-to-day work activities at different locations other than their traditional offices (Lei and Slocum, 2002 cited in Hloma and Ortlepp, 2006:29).

\section{CONCLUSION}

The 'war for talent' has resulted in global organisations competing with local South African organisations for scarce talent and this has resulted in South African organisations adopting talent management strategies in order to reduce the negative impact of employee turnover. This study focused on the potential influence of a number of key factors on the potential turnover intentions of a sample of managerial-level employees specifically, as there is a global shortage of talented employees at the managerial level. The factors that were found to have the strongest influence were: management/leadership style; career-path strategies; and rewards. The findings from this study add to the growing pool of knowledge pertaining to the career management of talented staff in various organisational contexts. In particular, the findings from this study emphasise how critically important it is that organisations give far more explicit attention to developing strategies related to fostering enabling management/leadership styles in their organisations, together with innovative career-path and reward strategies. This is essential if organisations are to achieve success in their endeavours to attract and retain key managerial-level personnel within the context of the ongoing global 'war for talent'.

\section{REFERENCES}

Armstrong, M. (2006) Human Resources Management. $9^{\text {th }}$ Edition. London: Kogan Page.

Beckstead, D \& Gellatly, G. (2004) "Are Knowledge Workers Only Found in High Technology Industries?" [Online] Available from: http://www.statcan.gc.ca/pub/11-622-m/11-622-m2004005-eng.pdf [Accessed 2008, 1 September]. 
Bethke, W. (2007) The secret to an effective bonus program. Review of Ophthalmology, 14 (12): 28-30.

Blake, R. (2006) "Why employees leave". [Online] Available from:

http://www.articlesbase.com/affiliate-programs-articles/why-employees-leave-58361.html[Accessed 2008, 16 August]

Blumberg, B., Cooper, D. \& Schindler, S. (2005) Business Research Methods. Berkshire: McGraw-Hill Higher Education: 455-460.

Brown, C. (2008) "Calculating Employee Turnover Rate". [Online] Available from: www.employeeretention-guide.com [Accessed 2008, 20 August].

Capelli, P. (2000) A market driven approach to retaining talent. Harvard Business Review 78(1):103-111.

Cook, P. (2006) Breaking the barriers to career progression. Engineering Management Journal, 16 (2): 31-33.

Daniels, R. (2007) "Skills Shortages in South Africa". [Online] Available from: http://www.commerce.uct.ac.za/research units/dpru/WorkingPapers/PDF Files/WP 07-121.pdf [Accessed 2008, 21 July].

Davis, S. (2010) "KwaZulu-Natal Economic Overview". [Online] Available from: www.sharondavis.co.za [Accessed 2010, 10 July].

Davies, G. (2008) Employer branding and its influence on managers. European Journal of Marketing, 42 (5/6): 668-669.

Day, V. (2000) Leadership development: A review in context. Leadership Quarterly 11(4):518 - 613. Department of Labour (2008) "National Scarce Skills List". [Online] Available from: http://www.mqa.org.za/siteimgs/NSDS\%20\%20Scarce\%20Skills\%20List\%202008,\%20Final\%20(2).pdf [Accessed 2008, 16 October].

Du Brin, A. (2008) Essentials of Management. $8^{\text {th }}$ Edition, Ohi: South-Western Cengage Learning: 350 360.

Erasmus, B, Loedolff, P, Mda, T \& Nel, P. (2006) Managing Training and Development in South Africa. Cape Town: Oxford University Press Southern Africa.

Felps, W., Mitchell, T.R., Hekman, D.R., Lee, T.W., Holtman, B.C., \& Harman, W.S. (2009) "Turnover contagion: How co-workers job embeddedness and job search behaviours influence quitting". Academy of Management Journal, 52 (3).[Online] Available from: http://www.ioatwork.com/ioatwork/2009/08/bewarethe-turnover-bug-its-contagious.html. [Accessed 2008, 28 July].

Fisher, C, Schoenfeldt, L \& Shaw, J. (2003). Human Resources Management. $5^{\text {th }}$ Edition, Miami: Houghton Mifflin.

Frauenheim, E. (2010) "Bosses don't drive workers away, poll concludes" Workforce Management Journal, 89 (4):1 [Online] Available from:

http://web.ebscohost.com/ehost/detail?vid=4\&hid=113\&sid=ef2b0cce-e728-4656981f50788fbd30f4\%40sessionmgr113\&bdata $=$ JnNpdGU9ZWhvc3QtbGl2ZQ\%3d\%3d\#db=a9h\&AN=4914 $\underline{8778}$.

French, W. (2003) Human Resources Management. Miami: Houghton Mifflin Company: 101-180. 
Gilley, J \& Maycunich, A. (2000) Beyond the Learning Organisation. New York: Perseus Books.

Grobler, P, Warnich, S, Carrell, N, Elbert, D \& Hatfield, R. (2006) Human Resources in South Africa, $6^{\text {th }}$ Edition. London: Thompson Learning.

Harman, W., Lee, T., Mitchell, T., Felps, W. \& Owens, B. (2007) The Psychology of Voluntary Employee Turnover. Current Directions in Psychological Science Journal, 16 (1): 51-54.

Hloma, X \& Ortlepp, K. (2006) People management implications of virtual workplace arrangements. Acta Commercii, 6:28-38.

Hom, P \& Griffeth, R. (1995) Employee Turnover. Ohio: South-Western College Publishing.

Hunter, C. (2008) Managing People in South Africa: a systematic approach to Human Resources Management. Pietermaritzburg: Bytes Document Solutions.

Isaacson, L. (2007) The international skills portal. HR Highway, 1(4):26 - 27.

Joubert, D. (2007) Talent Management: deliberate practice for success. Cape Town: Knowres Publication.

Kinnear, L \& Sutherland, M. (2000) Don't let your competitive advantage walk out the door. South African Journal for Business Management, 31 (3):22 - 25.

Lowenthal, K. (2001) An Introduction to Psychological Tests and Scales, $2^{\text {nd }}$ Edition. New York: Psychology Press.

Luyt, D (2008) "Governance, Accountability and Poverty Alleviation in South Africa". [Online] Available from:

http://www2.ohchr.org/english/issues/poverty/docs/sforum/spresentations/D.Luyt.pdf [Accessed 2008, 15 November].

Mostert, K \& Koekmoer, L. (2007) "Experiences of Work/Life Balance in South Africa". [Online] Available from: http://www.puk.ac.za/opencms/export/system/galleries/pics/puk-fak-ekonworkwell/newsletter2 apr2007.pdf [Accessed 2008, 26 August].

Nel, P, Werner, A, Haasbroek, G, Poisat, P, Sono, T \& Schultz, H. (2008) Human Resources Management. $7^{\text {th }}$ Edition. Cape Town: Oxford Southern Africa.

Nelson, B \& Spitzer, D. (2003) The 1001 Rewards and Recognition Fieldbook. New York: Workman Publishing.

Nxele, M. (2008) "Challenges on talent acquisition and retention in an era of 'Brain Drain'". [Online] Available from: http://www.ituglobalsymposium2008.info/Doc.19-Mike\%20Nxele-ITU.doc [Accessed 2008, 11 December].

Pop, M. \& Pop. T. (2008) Types of management and management styles. Fascicle of Management and Technological Engineering, VII (XVII): 2604-2606.

Ryan, T. (2009) Ask the right questions. Mail \& Guardian, April 2, p2.

Sandweiss, D \& Lewin, D. (2000) Interviews with part-time MBAs point the way for retaining executive track managers. Employment Relation Today Journal, Spring Volume: 21 - 46. 

of South African management-level employees.

Schreuder, A. \& Coetzee, M. (2006) Careers: An Organisational Perspective. $3^{\text {rd }}$ Edition. Landsome: Juta and Company, $48-62$.

Sekuguchi, T. (2004) "Person - Organisation Fit and Person - Job Fit in Employee Selection: A review of the literature". [Online] Available from: http://www.osaka-

ue.ac.jp/gakkai/pdf/ronshu/2003/5406 ronko seiguti.pdf [Accessed 2008, 26 August].

Shore, T., Tashchian, A. \& Jourdan, L. (2006) Effects of internal and external pay on work attitudes. Journal of Applied Social Psychology, 36 (10): 2578-2582.

Taylor, G. (2003) Talent management strategies. People Dynamics, 21(7): 5- 7.

Vansickle, J. (1999) "Treat your employees right". [Online] Available from:

http://nationalhogfarmer.com/mag/farming treat employees right/ [Accessed 2009, 27 January].

Zikmund, W. (2003) Business Research Methods. $5^{\text {th }}$ Edition, Florida: Dryden Press. 